\title{
Softball Batting Exercise Model for Beginner Athletes
}

\author{
Muhammad Fahrezi Harahap ${ }^{1}$, Iman Sulaiman ${ }^{2}$, Yasep Setiakarnawijaya ${ }^{3}$ \\ ${ }^{1,2,3}$ Postgraduate Sports Education in Jakarta State University, Indonesia \\ fahrezi994@gmail.com
}

\begin{abstract}
This research and development was conducted to produce exercise model of softball batting based on drill for beginner athletes by testing the effectiveness of softball batting training for beginner athletes. The development method used took the steps of Borg and Gall. To support data to be more valid, the process of analyzing data collection used observation, interviews, and tests. The batting exercise model was designed by combining drill-based training activities. After that the model item design was validated by 3 experts in their field, 1 softball lecturer, 1 softball coach, and 1 motor expert. The study involved 20 athletes consisting of 3 softball clubs in Medan. Increasing battingsoftball training during the pre-test showed tcount $=-21,225, d f=19$ and $p$-value $=0,00<0,05$, meaning that there were significant differences in softball batting training model before and after being given a training model. It could be concluded that the model of training developed effectively to enhance batting exercises developed was effective for enhancing batting exercises for beginner athletes.
\end{abstract}

Keywords : training; softball batting; drill; beginner athletes

\section{Introduction}

Jakarta is an area that can be said to successfully build the generation of softball athletes. West Java can also be said to successfully build a generation of softball athletes. It's just that other regions, such as North Sumatra that is still minimal in the generation of athletes, but slowly in North Sumatra begin in the stage of improvement in the selection of athletes and socializing softball in schools in North Sumatra.

Based on existing data, softball in North Sumatra Province is still less attractive to the public in general, unlike the case with popular sports such as futsal, soccer and badminton. The selection of softball athletes in North Sumatra is very minimal. How not, from 25 districts and 8 cities in SUMUT, there are only 4 clubs from this sport and this is in the capital of North Sumatra Province. Of these 4 clubs only a few were active in their weekly training. While in Medan city which has 4 clubs, baseball and softball, is the $4^{\text {th }}$ largest city in Indonesia. With the lack of clubs in the province not accompanied by events, sports events are also not often carried out, so marketing the sport to the public is also not good.

Therefore, a lot of problems were encountered when talking about this sport, starting from the infrastructure, people's interest in sports ball, regeneration of clubs to find great athletes. In this study the author will examine one of the clubs in North Sumatra, namely USBC, where the club is always constant or always managed to regenerate softball athletes, even though it is still at the provincial level.

However, apart from this generation of athletes, one of the internal problems of this club is the basic technique that is still not evenly distributed. Even in terms of the basic techniques of softball athletes themselves, there are still many who experience problems in terms of basic techniques, especially hitting. Many athletes often make mistakes in performing techniques in softball, and that is a factor in the athlete's mistakes or problems. In this case, the author observes in the field and the author talks about what are the obstacles to the technique. Of the several techniques that exist in this sport, the author raised the technique of hitting, according to the conditions in the field at the time of observation and talking with the club's coach. Athletes still experience errors when doing basic hitting techniques, there are still late hits when 
the ball is thrown, athletes also too fast when swinging the bat before the ball reaches the strike zone, and the athlete still lacks concentration when already in the batterbox. Factors that affect failure in hitting are: (1) A better view is not focused on seeing the upcoming ball, (2). The slow rotation of the hand when the ball reaches the strike zone causes the athlete to be late to hit, (3). Hand rotation speed that cannot be balanced when the ball has not reached the strike zone, resulting in failure to hit, (4). Poor standing position also affects the failure of the hit, because pitchers who come in the outsidenamunbatter area stand too close to the batterbox and vice versa, (5). Batter readiness also affects failure to hit, due to nervous batter, lack of confidence, and concentration.

The softball game has several basic techniques such as throwing, catching, and hitting. At the time of defense, the technique throws and catches it is needed in this game. While at the time of attack hit that must be considered. The game situation is offense, the thing that is done to start the attack is with one of the players (batter) entering batter's box to hit the ball the opponent's pitcher throws. One of the successes in attack is the batter's ability to hit the ball thrown by the pitcher (Sabarini, 2008). For beginners, the technique must be taught first, especially the hitting technique. Hitting is one of the most important techniques in this sport. When you don't have the skills to hit the player will not get points. This makes softball coaches emphasize their players more often practice hitting skills than other skills. That is because in hitting teaching requires a long enough time to train it, so that these skills can be mastered well (Rihatno \& Gunawan, 2014).

Given the importance of mastering the ability to hit a softball, then in practice this ability must take precedence by training the basic motion of hitting, so that each player will be able to hit the softball ball well to get value, or help friends in one team pass the next base, to support the team in winning every match (Rybeto, 2010).

From the explanation above, that the importance of hitting techniques in softball is very important, because by hitting that one will get the value to achieve victory. If athletes are lacking in terms of hitting, then a strategy will not work well. Therefore researchers will examine in terms of hitting techniques, to train and improve punch results in softball games. Previous research conducted by Ridho Nofebri Yanto, explained that batting can be increased by horizontal swing exercises. But in this study, no forms of training were described that would improve batting results.

Basically, Tossball and Softball is a form of horizontal swing training using tools and balls. How to practice for this tossball and softtossball, the ball is tossed from below and from the side. For both of these exercises it aims to train swing accuracy with ball exposure and train eye coordination, and provide experience to batter in all zone areas (Dumadi, 2018).

\section{Research Methods}

Research on the batting practice model on this softball game uses research and development (R \& D) methods from Borg and Gall. According to Borg \& Gall as quoted by Punaji (2010: 194), research and development is a process used to develop or validate products used in learning education (Arman, Gugus Puji, Sulaiman, \& Rustiadi, 2013). The approach which is used in this study is a quantitative approach. It is an approach to finding answers to problems through the formulation of the problems that have been formulated above, namely the model of softball batting training for beginner athletes. 
The final result of this development research is the softball batting training model which will produce a new product in the form of a new training model design that has been tested for its complete feasibility with product specifications while testing the effectiveness of the training model so that it can improve accuracy and quality and it can be used as a reference for the trainer in the activity of training softball batting technique skills.

In the research on the development of the batting practice model in this softball game, the next process is to determine the steps of the research phase to be carried out.

\subsection{Research Steps}

The steps of research and development developed by Borg and Gall include:

a. The first step that must be taken is to determine the idea that will be developed, R \& D can depart from the potential of the problems around.

b. Gather information; after the potential and problems can be shown factually, further information needs to be collected which can be used as material for planning.

c. Product design is the result of a series of preliminary studies, which in this study were battingsoftball training models for beginner athletes.

d. Design validation is the process of assessing training models by experts.

e. Design improvements.

f. Limited product testing by practicing a training model at school

g. Product revisions are based on the results of field tests.

h. Test usage in actual conditions.

i. Revision of the product again if found to be deficient in actual conditions

j. Mass product manufacture after repair.

In the explanation above, the steps below can be described:

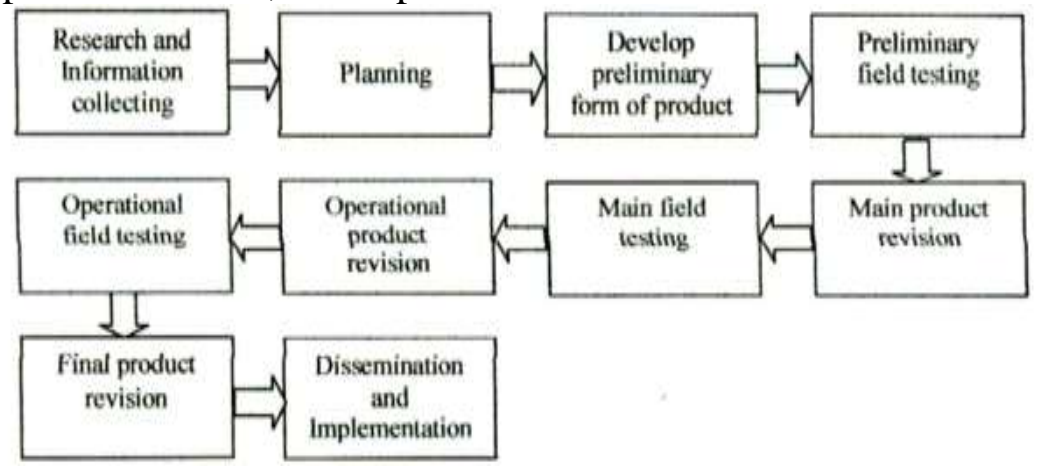

Figure 1. Steps in R \& D Research according to Borg and Gall

\subsection{Model Development Planning}

The development of training models is expected to be a new product that can be developed systematically and logically, so that this product has the effectiveness and efficiency that is feasible to use. The development of training models is expected to be a product that can be developed systematically and logically, so that this product has the effectiveness and efficiency that is feasible to use.

In making products developed by researchers, researchers must consult products on softball experts to produce the perfect product.

Every softball batting, researchers apply a training model that is adjusted to batting to be trained, because there are different forms of batting. Therefore the researchers make 4 forms of batting exercises where in each form of exercise itself 3 types of exercises namely; easy, 
medium and difficult. For more details, the researchers will explain below the form of training that will be made.

\section{A. Toss ball}

1) Easy

- Workout item 1: hit the ball with a racket

- Item workout 2: hit the badminton ball with batt

- Item exercise 3: catch the softball ball by hand

2) Medium

- Item workout 4: hit the color ball mentioned by the thrower

- Exercise item 5: hit the ball with batt in the right hand

- Item exercise 6: hit the ball from the side

3) Difficult

- Item workout 7: hit a plastic ball with a tilted racket position

- Item exercise 8: hit the ball coming from behind

- Item exercise 9: hit the ball that comes with a barrier

B. Self Toss Ball

1) Easy

- Item exercise 10: hit the tennis ball from the reflection itself

- Workout item 11: hit your own reflected tennis ball with the original batt

- Workout item 12: hit badminton ball with batt

- Workout item 13: hit the softball ball with batt

2) Medium

- Workout item 14: hit the ball on top

- Workout item 15: hit your own bounce tennis ball with a tilted racket

- Workout item 16: hit the hanging ball

3) Difficult

- Item exercise 17: hit the badminton ball thrown yourself

- Workout item 18: hit a softball ball that is thrown yourself

C. Incline Swings

1) Easy

- Workout item 19: hit the softball ball with batt from the thrower

- Workout item 20: hit a softball ball that is thrown yourself

-Workout item 21: hit the softball ball reflected on the wall

2) Medium

- Workout item 22: hit the ball with your left foot on the tire

- Exercise item 23: hit the ball with the right foot on the tire

3) Difficult

- Item exercise 24: hit the ball above the standing tire with one right hand

- Exercise item 25: hit the ball in a squat position, the left foot straightens to the side

- Exercise item 26: hit the ball in a squat position with a bat in the right hand

C. Step Back

1) Easy

- Workout item 27: hit the ball yourself, then the left foot rises to the beam on the side

- Exercise item 28: hit the ball yourself, with the right foot on the tire 
2) Medium

- Workout item 29: hit a friend's throw ball with your left foot banned

- Workout item 30: hit a friend's throw ball with your right foot on a tire

- Workout item 31: hit the ball with batt and go straight up to the tire

3) Difficult

- Workout item 32: hit a friend's throwing ball while taking steps

- Workout item 33: hit a friend's throwing ball while stepping and your left foot goes straight to the tire

\subsection{Model Feasibility}

\section{Discussion}

After doing the data collection stage and drafting the batting practice model on ssoftball sports, the next step is to test the experts where the goals to be achieved are to get the feasibility or validity of the models made by direct assessment from experts.

In the research that the researchers did, researchers presented 3 experts in evaluating the feasibility of training model that the researchers made. Where 1 person works as a softball lecturer, 1 person as a training lecturer, and 1 person as a trainer.

The conclusions from the expert test conducted can be explained in the table below:

Table 1. Model feasibility

\begin{tabular}{|c|c|c|c|c|}
\hline \multirow[b]{2}{*}{ No } & \multirow[b]{2}{*}{ Name } & \multicolumn{2}{|c|}{$\begin{array}{c}\text { Acceptance } \\
\text { Model }\end{array}$} & \multirow[b]{2}{*}{ Information } \\
\hline & & $\begin{array}{c}\text { Ye } \\
\text { s }\end{array}$ & No & \\
\hline 1 & Item Model Batting1 & & $\sqrt{ }$ & Unfeasible \\
\hline 2 & Item Model Batting 2 & $\sqrt{ }$ & & Feasible \\
\hline 3 & Item Model Batting3 & $\sqrt{ }$ & & Feasible \\
\hline 4 & Item Model Batting4 & $\sqrt{ }$ & & Feasible \\
\hline 5 & Item Model Batting5 & $\sqrt{ }$ & & Feasible \\
\hline 6 & Item Model Batting6 & & $\sqrt{ }$ & Unfeasible \\
\hline 7 & Item Model Batting 7 & & $\sqrt{ }$ & Unfeasible \\
\hline 8 & Item Model Batting 8 & $\sqrt{ }$ & & Feasible \\
\hline 9 & Item Model Batting 9 & $\sqrt{ }$ & & Feasible \\
\hline 10 & Item Model Batting 10 & & $\sqrt{ }$ & Unfeasible \\
\hline 11 & Item Model Batting 11 & $\sqrt{ }$ & & Feasible \\
\hline 12 & Item Model Batting 12 & $\sqrt{ }$ & & Feasible \\
\hline 13 & Item Model Batting 13 & $\sqrt{ }$ & & Feasible \\
\hline 14 & Item Model Batting 14 & $\sqrt{1}$ & & Feasible \\
\hline 15 & Item Model Batting 15 & $\sqrt{ }$ & & Feasible \\
\hline 16 & Item Model Batting 16 & $\sqrt{ }$ & & Feasible \\
\hline 17 & Item Model Batting 17 & $\sqrt{ }$ & & Feasible \\
\hline 18 & Item Model Batting 18 & $\sqrt{ }$ & & Feasible \\
\hline 19 & Item Model Batting 19 & $\sqrt{ }$ & & Feasible \\
\hline 20 & Item Model Batting 20 & $\sqrt{ }$ & & Feasible \\
\hline 21 & Item Model Batting 21 & $\sqrt{ }$ & & Feasible \\
\hline 22 & Item Model Batting 22 & $\sqrt{ }$ & & Feasible \\
\hline
\end{tabular}




\begin{tabular}{|c|c|c|c|c|}
\hline \multirow{2}{*}{ No } & \multirow{2}{*}{ Name } & \multicolumn{2}{|c|}{$\begin{array}{c}\text { Acceptance } \\
\text { Model }\end{array}$} & \multirow{2}{*}{ Information } \\
\hline & & $\begin{array}{c}\text { Ye } \\
\mathbf{S}\end{array}$ & No & \\
\hline 23 & Item Model Batting 23 & $\sqrt{ }$ & & Feasible \\
\hline 24 & Item Model Batting 24 & $\sqrt{ }$ & & Feasible \\
\hline 25 & Item Model Batting 25 & $\sqrt{ }$ & & Feasible \\
\hline 26 & Item Model Batting 26 & $\sqrt{ }$ & & Feasible \\
\hline 27 & Item Model Batting 27 & $\sqrt{1}$ & & Feasible \\
\hline 28 & Item Model Batting 28 & $\sqrt{ }$ & & Feasible \\
\hline 29 & Item Model Batting 29 & $\sqrt{ }$ & & Feasible \\
\hline
\end{tabular}

Based on expert tests conducted, it can be concluded that variations in the training model on softball sports are feasible and can be used in batting exercises on softball for beginner athletes.

Expert tests carried out by researchers on three experts have some constructive suggestions for perfecting the batting softball model, among them.

1) The instructions and implementation of batting movements must be made more clearly to make it easier for athletes to do so.

2) The drawing of the batting exercise model must be clear.

3) Models must be absolutely safe to avoid athletes from injury when doing batting exercises.

4) Submission or demonstration to athletes must be clear to make it easier for athletes to understand when doing batting exercises.

5) Each training model item must be related to batting so as not to run away from the training objectives.

\subsection{First Stage Results / Trial of Small Groups}

After conducting an evaluation stage to experts / experts on the batting model of softball sports, the researchers tested the product in a small group with 10 athletes. The following is a summary of the results of small group trials:

Table 2. Summary of Small Trial Results

\begin{tabular}{ccl} 
No & \multicolumn{1}{c}{ Model } & \multicolumn{1}{c}{ Suggestions and Feedback } \\
\hline 1 & Item Model Batting 1 & $\begin{array}{l}\text { This model can be applied to train batting } \\
\text { skills because it can already be done }\end{array}$ \\
\hline 2 & Item Model Batting 2 & $\begin{array}{l}\text { This model can be applied to train batting } \\
\text { skills because it can already be done }\end{array}$ \\
\hline 3 & Item Model Batting 3 & $\begin{array}{l}\text { This model can be applied to train batting } \\
\text { skills because it can already be done }\end{array}$ \\
\hline 4 & Item Model Batting 4 & $\begin{array}{l}\text { This model can be applied to train batting } \\
\text { skills because it can already be done }\end{array}$ \\
\hline 5 & Item Model Batting 5 & $\begin{array}{l}\text { This model can be applied to train batting } \\
\text { skills because it can already be done }\end{array}$ \\
\hline 6 & Item Model Batting 6 & $\begin{array}{l}\text { This model can be applied to train batting } \\
\text { skills because it can already be done }\end{array}$ \\
\hline 7 & Item Model Batting 7 & $\begin{array}{l}\text { This model can be applied to train batting } \\
\text { skills because it can already be done }\end{array}$
\end{tabular}




\begin{tabular}{|c|c|c|}
\hline No & Model & Suggestions and Feedback \\
\hline 8 & Item Model Batting 8 & $\begin{array}{l}\text { This model can be applied to train batting } \\
\text { skills because it can already be done }\end{array}$ \\
\hline 9 & Item Model Batting 9 & $\begin{array}{l}\text { This model can be applied to train batting } \\
\text { skills because it can already be done }\end{array}$ \\
\hline 10 & Item Model Batting 10 & $\begin{array}{l}\text { This model can be applied to train batting } \\
\text { skills because it can already be done }\end{array}$ \\
\hline 11 & Item Model Batting 11 & $\begin{array}{l}\text { This model can be applied to train batting } \\
\text { skills because it can already be done }\end{array}$ \\
\hline 12 & Item Model Batting 12 & $\begin{array}{l}\text { This model can be applied to train batting } \\
\text { skills because it can already be done }\end{array}$ \\
\hline 13 & Item Model Batting 13 & $\begin{array}{l}\text { This model can be applied to train batting } \\
\text { skills because it can already be done }\end{array}$ \\
\hline 14 & Item Model Batting 14 & $\begin{array}{l}\text { This model can be applied to train batting } \\
\text { skills because it can already be done }\end{array}$ \\
\hline 15 & Item Model Batting 15 & $\begin{array}{l}\text { This model can be applied to train batting } \\
\text { skills because it can already be done }\end{array}$ \\
\hline 16 & Item Model Batting 16 & $\begin{array}{l}\text { This model can be applied to train batting } \\
\text { skills because it can already be done }\end{array}$ \\
\hline 17 & Item Model Batting 17 & $\begin{array}{l}\text { This model can be applied to train batting } \\
\text { skills because it can already be done }\end{array}$ \\
\hline 18 & Item Model Batting 18 & $\begin{array}{l}\text { This model can be applied to train batting } \\
\text { skills because it can already be done }\end{array}$ \\
\hline 19 & Item Model Batting 19 & $\begin{array}{l}\text { This model can be applied to train batting } \\
\text { skills because it can already be done }\end{array}$ \\
\hline 20 & Item Model Batting 20 & $\begin{array}{l}\text { This model can be applied to train batting } \\
\text { skills because it can already be done }\end{array}$ \\
\hline 21 & Item Model Batting 21 & $\begin{array}{l}\text { This model can be applied to train batting } \\
\text { skills because it can already be done }\end{array}$ \\
\hline 22 & Item Model Batting 22 & $\begin{array}{l}\text { This model can be applied to train batting } \\
\text { skills because it can already be done }\end{array}$ \\
\hline 23 & Item Model Batting 23 & $\begin{array}{l}\text { This model can be applied to train batting } \\
\text { skills because it can already be done }\end{array}$ \\
\hline 24 & Item Model Batting 24 & $\begin{array}{l}\text { This model can be applied to train batting } \\
\text { skills because it can already be done }\end{array}$ \\
\hline 25 & Item Model Batting 25 & $\begin{array}{l}\text { This model can be applied to train batting } \\
\text { skills because it can already be done }\end{array}$ \\
\hline
\end{tabular}

Based on a small group trial evaluation conducted by several experts, it can be concluded as follows:

1) When doing batting exercises, the coach must supervise and give direction when the athlete makes a move that is not in accordance with the instructions.

2) The model must be emphasized again to the athlete to be able to carry out well.

3) Athlete's enthusiasm for the training model given is able to increase the spirit of the athlete's training in batting practice. 
4) The compilation of models made starting from the easy, medium, and difficult stages has been arranged well.

The small group trial results conducted on 32 models of batting exercises for beginners evaluated by experts, based on the results of the analysis of each model found that the training model that was less effective was evaluated and then improved and used for large group trials.

\subsection{Second Stage Results / Large Group Trials}

After the results of the product development model of batting training in softball sports, it was tested on a small scale and have been revised, then the next stage is conducting large group trials. Based on the results of a small group trial, the researcher then revised the initial product and obtained 25 models of batting exercises on softball which will be used in large group trials.

After the product has undergone a revision in second stage, it is continued by testing products to more athletes or large trials of 30 athletes consisting of 3 softball clubs namely, USBC, INCA, and Gladiators in Medan.

The results of a large group trial conducted on 25 models of batting exercises for beginners to get advice and input from experts and experts to be improved to make it better, while the suggestions and input given by experts in this training model include:

1) Pay attention to the athlete when doing the exercise model given whether it is in accordance with the implementation.

2) The trainer must be able to explain and practice the training model provided so that the athlete is able to understand.

3) Experts state the effectiveness of modeling a batting exercise for beginners is already effective in helping softball coaches to do batting exercises.

\subsection{Model Effectiveness}

\section{1) Effectiveness Results}

After the results of the development of batting softball training products were tested on a small scale and have been revised, and conducted a large group trial then continued the effectiveness test. The next step after the model underwent a second stage, then continued testing the product to the effectiveness group using research subjects 20 athletes at the club softball terrain. The research data using 20 athletes on the effectiveness of the batting softball training model is shown in the following table:

Table 3 Pretest Data and Posttest

\begin{tabular}{cccc} 
No & Pretest & Posttest & Difference \\
\hline $\mathrm{x} 1$ & 5 & 11 & 6 \\
\hline $\mathrm{x} 2$ & 6 & 15 & 9 \\
\hline $\mathrm{x} 3$ & 5 & 12 & 7 \\
\hline $\mathrm{x} 4$ & 7 & 15 & 8 \\
\hline $\mathrm{x} 5$ & 10 & 23 & 13 \\
\hline $\mathrm{x} 6$ & 6 & 16 & 10 \\
\hline $\mathrm{x} 7$ & 6 & 20 & 14 \\
\hline $\mathrm{x} 8$ & 7 & 15 & 8 \\
\hline $\mathrm{x} 9$ & 9 & 20 & 11
\end{tabular}




\begin{tabular}{cccc}
$\mathrm{x} 10$ & 7 & 18 & 11 \\
\hline $\mathrm{x} 11$ & 6 & 16 & 10 \\
\hline $\mathrm{x} 12$ & 7 & 16 & 9 \\
\hline $\mathrm{x} 13$ & 9 & 19 & 10 \\
\hline $\mathrm{x} 14$ & 8 & 16 & 8 \\
\hline $\mathrm{x} 15$ & 9 & 20 & 11 \\
\hline $\mathrm{x} 16$ & 7 & 18 & 11 \\
\hline $\mathrm{x} 17$ & 8 & 17 & 9 \\
\hline $\mathrm{x} 18$ & 7 & 19 & 12 \\
\hline $\mathrm{x} 19$ & 10 & 23 & 13 \\
\hline $\mathrm{x} 20$ & 9 & 21 & 12 \\
\hline Total & 148 & 350 & 202 \\
\hline
\end{tabular}

The table above presents a table of pretest and posttest softball batting skills for beginner athletes. The pretest was conducted after a small group revision.

Table 4. Results of Paired Samples Statistics Pretest and Posttest

\begin{tabular}{llllll} 
& Mean & $\mathrm{N}$ & $\begin{array}{c}\text { Std. } \\
\text { Deviation }\end{array}$ & $\begin{array}{c}\text { Std. } \\
\text { Error } \\
\text { Mean }\end{array}$ \\
\hline Pair 1 & PRETEST & 7.4000 & 20 & 1.53554 & .34336 \\
\hline & POSTTEST & 17.5000 & 20 & 3.22000 & .72001
\end{tabular}

The average results of athletes before being given a training model are equal to. 433636 and the results after being given the treatment of developing a batting exercise model. Softball for beginner athletes is equal to .72001 which means that there is an increase in pretest and posttest so batting practice Softball for beginner athletes can be said to increase.

Table 5. Results of Paired Samples Correlations Pretest and Posttest

Paired Samples Correlations

\begin{tabular}{|c|c|c|c|c|}
\hline & \multirow{2}{*}{$\begin{array}{c}\text { PRETEST } \\
\& \\
\text { POSTTEST }\end{array}$} & $\mathrm{N}$ & Correlation & Sig. \\
\hline & & 20 & .83 & .000 \\
\hline
\end{tabular}

Based on the table above, it was found that the correlation coefficient of batting training forball for beginner athletes before and after the treatment of batting practice models was given. Softball for beginner athletes was. $830 \mathrm{p}$-value $0.00<0.05$ so the conclusion was that there was a significant relationship.

Table 6. Results of Paired Sample Test Pretest and Posttest

\section{Paired Samples Test}




\begin{tabular}{|c|c|c|c|c|c|c|c|c|c|}
\hline \multicolumn{10}{|c|}{ Paired Differences } \\
\hline & & \multirow[t]{2}{*}{ Mean } & \multirow{2}{*}{$\begin{array}{c}\text { Std. } \\
\text { Deviation }\end{array}$} & \multirow{2}{*}{$\begin{array}{l}\text { Std. Er } \\
\text { or } \\
\text { Mean }\end{array}$} & \multicolumn{2}{|c|}{$\begin{array}{l}95 \% \text { Confidence } \\
\text { Interval of the } \\
\text { Difference }\end{array}$} & \multirow[t]{2}{*}{$\mathrm{t}$} & \multirow[t]{2}{*}{ df } & \multirow{2}{*}{$\begin{array}{l}\text { Sig. } \\
(2- \\
\text { tailed })\end{array}$} \\
\hline & & & & & Lower & Upper & & & \\
\hline Pair 1 & $\begin{array}{c}\text { PRE } \\
\text { TEST } \\
- \\
\text { POST } \\
\text { TEST }\end{array}$ & $\begin{array}{c}- \\
10.10000\end{array}$ & 2.12504 & .47517 & -11.09455 & -9.10545 & -21.255 & 19 & .000 \\
\hline
\end{tabular}

The significance difference between SPSS 24 shows that the mean $=-10.10000$ shows the difference between the results of the pretest and posttest results, the results of t-score $=$ $21.225 \mathrm{df}=19$ and $\mathrm{p}$-value $=0.00<0.05$, which means there are significant differences between before and after giving treatment of batting practice models Softball for beginner athletes.

The following is a comparison of the results of the results of the athletes who have not been given treatment in the Softball (pretest) batting training model with the athletes who have been given the treatment of the batting practice model, Softball (post test) based on the diagram:

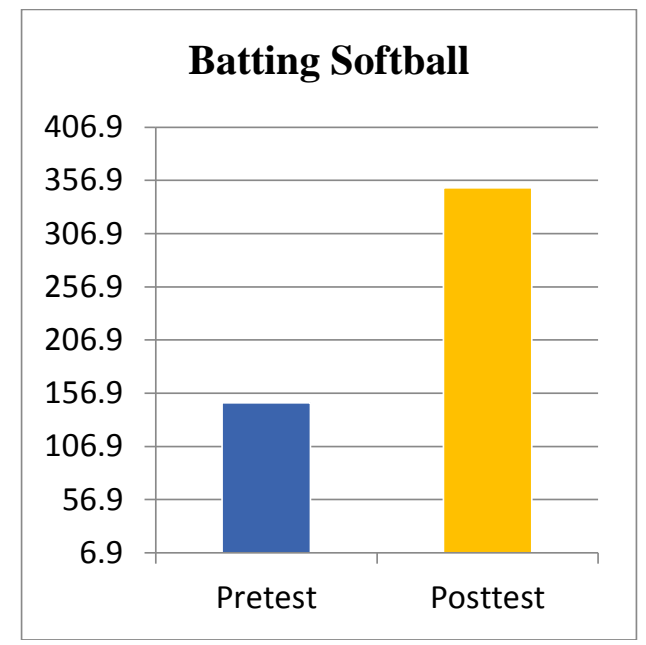

Figure 2. Bar chart (large group trial)

After being seen from the results of the above calculations between the small group test on the large group test it can be concluded that the Softball batting exercise model for beginner athletes can be used in training and is effectively used to improve batting exercises Softball for beginner athletes.

\subsection{Discussion}

The batting exercise model created by researchers is a product that aims to assist trainers in delivering batting softball training material, improving athletes' batting abilities, and as a reference for training materials. The softball batting exercise model is made based on the level of children's needs in training activities especially in batting training activities on softball sports.

This product after reviewing several weaknesses that need improvement, can be conveyed several advantages of this product, including: 
1) Improve batting skills of beginner athletes in softball sports.

2) This model can make athletes more active and enthusiastic in batting exercises on softball.

3) The model of batting softball training is more effective and efficient.

4) As a reference trainer in doing batting softball exercises

5) This model of softball batting exercise is done systematically from easy to difficult.

6) The model used is very varied which can increase the level of anti-athlete athletes in training.

\section{Conclusion}

Based on data obtained from the results of small group trials and large group trials as well as discussion of the results of the study, there are some conclusions, that:

1) Exercises model of softball batting based on drill can be developed and applied to athletes during batting exercises.

2) Exercises model of softball batting based on drill that have been developed, obtained data on the effectiveness and results of softball training models for beginner athletes.

\section{References}

Arman, Gugus Puji , Sulaiman, \&Rustiadi, T. (2013). Model Pengembangan Permainan Takraw Asik Dalam Pembelajaran Penjasorkes Bola Besar Pada Siswa Kelas V Sekolah Dasar. Journal of Physical Education, Sport, Health and Recreations, 2(3).

Badriah, D. (2012). Metodologi Penelitian Ilmu-Ilmu Kesehatan. Bandung: Multazam.

Budiwanto, S. (2004). Pengetahuan Dasar Melatih Olahraga. Ma: Jurusan Ilmu Keolahragaan FIP UM.

Budiwanto, S. (2012). Metodologi Latihan Olahraga. Malang: UM Press.

Christina, Y.H, Sasminta \& Kritiyandaru, A. (2011). Petunjuk Praktis Bermain Softball. Malang: Wineka Media.

D.Gall,Maredith \& Borg, R. W. (2007). Eighth Edition Educational Research. USA.

Darmadi, H. (2011). Metodologi Penelitian Pendidikan. Bandung: Alfabeta.

Dewi, Wahyu Putri Vembriana \& Pujianto, A. (2015). Model Pengembangan Permainan Fun Hockey Pada Siswa Kelas XI SMA Negeri 1 Bawang Kecamatan Bawang Kabupaten Batang Tahun 2014. Journal of Physical Education, Sport, Health and Recreations, 4 (7), 1963-1968.

Dumadi. (2018). Pengaruh Latihan Toss Ball dan Swing Batter Terhadap Hasil Pukulan Softball Tim UPGRIS 2018, 614-621.

Edwards, W. H. (n.d.). Motor Learning and Control From Theory to Practice.

Emzir. (2008). Metodologi Penelitian Pendidikan Kuantitatif \& Kualitatif. Jakarta: Raja Grafindo Persada.

Faizah, Y. (2003). Analisis Keperluan Latihan. Malaysian Journal of Social Administration.

Garman, J., Garman, J., \& Gromacki, M. (2011). Softball Skills \& Drills.

Gola, M. (2012). Winning Softball For Girls Second Edition. New York: Chelsea House.

Harjanto. (2008). Perencanaan Pengajaran. Bandung: Rineka Cipta.

Hasan, S., Winarno, M. E., \& Tomi, A. (2015). Pengembangan Model Permainan Gerak Dasar Lempar Untuk Siswa Kelas V Sdn Tawangargo 4 Karangploso Malang. Jurnal Pendidikan Olahraga, 4(2), 182-200.

Kartiko, W. R. (2010). Asas Metodologi Penelitian. Yogyakarta: Graha Ilmu.

Karyono, T. (2016). Pengaruh Metode Latihan Dan Power Otot Tungkai Terhadap Kelincahan Bulungtangkis. Jurnal Olahraga Prestasi, 12(1), 49-62.

Koenig, K., Mitchell, N. D., Hannigan, T. E., \& Clutter, J. K. (2004). The influence of moment of inertia on baseball/softball bat swing speed. Sports Engineering, 7 (2), 105-117. 
Budapest International Research and Critics in Linguistics and Education (BirLE) Journal

Volume 2, No 3, August 2019, Page: 494-505

e-ISSN: 2655-1470 (Online), p-ISSN: 2655-2647 (Print)

www.bircu-journal.com/index.php/birle

emails: birle.journal@gmail.com

birle.journal.qa@gmail.com

https://doi.org/10.1007/BF02915922

KS, S. (2010). Pengembangan Alat Ukur Keterampilan Dasar Bermain Softball. Cakrawala Pendidikan, (3), 280-293.

Lumintuarso, R. (2013). Teori Kepelatihan Olahraga. Jakarta: Lankor.

M.E. Winarno. (2011). Metode Penelitian Dalam Pendidikan Jasmani. Malang: Media Cakrawala Utama Press.

Nuraini, Sri \& Nugraha, H. (2018). Teori Dan Praktek Permainan Kecil. Jakarta: LPP Universitas Negeri Jakarta.

Permadi, A. (2015). Upaya Meningkatkan Hasil Pukulan Swing Dalam Permainan Softball Menggunakan Metode Resiprokal Pada Siswa Kelas VII SMP Negeri 3 Sei Suka Tahun Ajaran 2013-2014. Paedagogik Keolahragaan, 01(01), 29-43.

Putra, N. (2012). Research \& Development. Jakarta: Raja Grafindo.

Ramadhani, A. \& P. S. (2017). Pengembangan Latihan Teknik Dasar Judo Melalui Model Permainan untuk Pejudo Pemula Usia 8-12 Tahun. JurnalKeolahragaan, 5 (1), 1-11.

Rihatno, T., \& Gunawan, V. S. (2014). Efektitifitas Pembelajaran Menggunakan Media Video Dan Media Cermin Terhadap Hasil Belajar Bola Softball, 74-82.

Rosdiani, D. (2008). Model Pembelajaran Langsung Dalam Pendidikan Jasmani dan Kesehatan. Bandung: Alfabeta.

Rybeto, E. (2010). Perbedaan Pengaruh Latihan Pitched Ball Dan Tee Ball Terhadap Kemampuan Memukul Bola Softball Pada Team Softball Putri SMEA Kristen I Surakarta Tahun 2010.

Sabarini, S. S. (2008). Perbedaan Pengaruh Latihan Dan Koordinasi Mata Tangan Terhadap Keterampilan Bermain Baseball, 1-147.

Sagala, S. (2009). Konsep dan Makna Pembelajaran. Bandung: CV.Alfabeta.

Nurfitriani, M. (2017). Model Permainan Tradisional "Boy-boyan" Untuk Meningkatkan Perkembangan Sosial Anak SD. Pendidikan Dan Pembelajaran Sekolah Dasar, 1, 127-138.

Serniawan, C. R. (2008). Catatan Kecil Tentang Penelitian dan Pengembangan Ilmu Pengetahuan (1st ed.). Jakarta: Kencana.

Setyosari, P. (2013). Metode Penelitian Pendidikan dan Pengembangan. Jakarta: Prenada Media Group.

Shaleh, A. R. (2006). Madrasah Dan Pendidikan Anak Bangsa Visi, Misi, dan Aksi. Jakarta: Rajawali Pers.

Sugiyono. (2010). Metode Penelitian Pendidikan Pendekatan Kuantitatif, kualitatif, dan R\&D. Bandung: Alfabeta.

Tangkudung, James \& Puspitorini, W. (2012). Kepelatihan Olahraga "Pembinaan Prestasi Olahraga. Jakarta: Cerdas Jaya.

Tangkudung, J. (2016). Macam-Macam Metodologi Penelitian Uraian Dan Contohnya. Jakarta: Lensa Media Pustaka Indonesia.

Thomas, Kenny \& King, D. (2016). Baseball Steps To Success. Canada: Human Kinetics.

Walker, K. (2007). Softball Drill Book. Canada: Human Kinetics.

Wardani, D. (2009). Bermain Sambil Belajar. Edukasia.

Wicaksono. (2015). Kontribusi Antara Latihan Horizontal Swing Dan Bar Twist Terhadap Peningkatan Hasil Pukulan Dalam Permainan Softball. Pedagogik Keolahragaan, 01, 13-19.

Widiastuti. (2014). Belajar Keterampilan Gerak. Jakarta: FIK Universitas Negeri Jakarta.

Widiastuti. (2015). Tes dan Pengukuran Gerak. Jakarta: Raja Grafindo Persada.

Yanto, Ridho Nofebri, Slamet, \& Juita, A. (n.d.). Pengaruh Latihan Horizontal Swing Terhadap Hasil Pukulan Paada Atlet Pelatda Softball Putri Riau, 1-14. 